\title{
The Possible and the Impossible: Potentia absoluta and potentia ordinata Under Close Scrutiny
}

\begin{abstract}
The medieval debates about the 'absolute' and 'ordained' power of God highlight the different meanings of the concept of possibility. According to the Summa Halensis, the potentia absoluta involves willing the impossible, namely, that which is not predetermined by any metaphysical or moral order. The potentia ordinata, on the other hand, concerns the will for what is possible, whether metaphysically, logically, or morally. John Duns Scotus is famous for dogmatizing the theory of God's absolute and ordained power. According to his univocal concept of the will, both the divine will and the human will can want something de potentia absoluta and de potentia ordinata. While 'ordained power' refers to actions that are possible within the framework of laws given by God himself, deviation from those laws is possible not only for humans but also for God through the absolute power. Although the Summa Halensis is sometimes regarded as a forerunner of Scotus' approach to absolute and ordained power, this chapter shows that it develops its account only to explain the condition of possibility of human willing. Thus, it does not anticipate Scotus' idea of an arbitrary God who is capable of deviating from his own laws.
\end{abstract}

\section{Absolute Power and Moral Power in the Summa Halensis}

Medieval thinkers no doubt have the modal category of the 'possible' in mind when they use the terms 'power' (potentia) or 'thinkable' (possibile). There is even direct evidence for this, although in some cases the authors themselves do not seem to be entirely convinced of the convention of speech. William of Auvergne handed down the view of 'some' philosophers, according to which the modality of possibility was to be distinguished in the three realms of nature, morality and logic known from the Stoics and also to be given different names. The possible in the realm of nature is the possibility (potentia) which is different from reality; the possible in the realm of morality is the power of office (potestas); the possible in the realm of logic finally is the conceivable (possibilitas). ${ }^{1}$ This terminology did not become generally accepted

1 William of Auvergne, De Trinitate 8.33, ed. Bruno Switalski (Toronto: Pontifical Institute of Mediaeval Studies, 1976), p. 54; cf. William of Auvergne, De anima, in Opera Omnia (Frankfurt am Main: Minerva, 1963) vol. II, pt. 6, p. 92.

Ә OpenAccess. (C) 2021 Theo Kobusch, published by De Gruyter. (cc) BY-NC-ND This work is licensed under the 
in the Middle Ages, but it does show that from the 13th century onwards philosophical sensitivity to what can be called 'possible' increases. The Summa Halensis also knows the distinction between the logically possible and the possible within the realm of nature. ${ }^{2}$

This indeed also applies to the concept of divine power and also for human power, as Anselm of Canterbury had already advocated the univocity of moral concepts, and Duns Scotus would shortly thereafter speak of the same structure of human and divine will. ${ }^{3}$

The Franciscan doctrine of the power of God - i.e. the distinction between potentia absoluta and potentia ordinata - has its foundation in the Summa Halensis. Here the concept of the power of God, which is called potentia activa, nevertheless denotes a possible, which in certain respects resembles the possible of the passive power of matter. Just as prime matter (materia prima) is not determined in one form, but is indifferent to all forms (although it is thought of as having a disposition and is therefore already determined), so is the divine active power undetermined in itself, yet determined as a cause, which contains potentially infinite worlds, by a superordinate disposition. ${ }^{4}$

With regard to the impossible, a distinction must be made: the impossible in the arena of human statements or actions always refers to the 'nature of the matter.' However, if a possible or impossible is to be indicated in the area of divine foreknowledge or predestination or in the area of the divine at all - i.e. a metaphysical possibility or impossibility - then reference is made to the divine power. ${ }^{5}$ Even if it is

2 Alexander of Hales, Doctoris irrefragabilis Alexandri de Hales Ordinis minorum Summa theologica (SH) 4 vols (Quaracchi: Collegium S. Bonaventurae, 1924-48), I, P1, In1, Tr4, Q3, C1 (n. 151), p. 231: "Respondeo: Dicendum quod intentio "possibilis" solet dici de dicto et de re subiecta. Secundum quod dicitur de dicto, non pertinet ad praesentem quaestionem, quia dictum "possibile" dicitur respectu veritatis necessariae vel contingentis in dicto, quae quidem fundatur in affirmationibus et negationibus, et secundum omne genus causalitatis.' Also SH I, P1, In1, Tr4, Q3, C1 (n. 151), p. 232: 'Dicendum quod possibile secundum naturam dicitur duobus modis. Uno modo, cuius principium est natura sive cuius principium est in natura; alio modo, quod non est a potentia naturae, sed tamen est consuetum ut fiat in natura a causa superiori, secundum quod dicitur "consuetudo est altera natura," ut creatio et iustificatio et huiusmodi."

3 Cf. Theo Kobusch, Selbstwerdung und Personalität: Spätantike Philosophie und ihr Einfluß auf die Moderne (Tübingen: Mohr Siebeck, 2018), p. 321.

4 SH I, P1, In1, Tr4, Q1, M1, C3 (n. 133), p. 204: 'Et si obicitur quod in Deo est possibilitas ad infinitos mundos, ergo possibile est infinitos mundos creari: dicendum quod sicut in prima materia est prima potentia passiva, ita in Deo est prima potentia activa; prima autem materia, quantum est de sua prima potentia, non est determinata ad aliquam formam, sed indifferens ad omnes; sed tamen intelligitur materia cum aliqua dispositione: et sic est determinata ad aliquam formam. Similiter dicendum de potentia Dei activa quia est potentia indeterminata, quae se habet ad infinitos mundos et secundum hoc est potentia in causa ad infinitos mundos, et est potentia determinata per dispositionem praeordinatam.'

5 SH I, P1, In1, Tr5, S2, Q4, Ti1, M4, C3 (n. 233), p. 327: '(...) quia in dictis vel factis hominum impossibilitas refertur ad naturam rei, in praescientia et praedestinatione refertur possibilitas vel impossi- 
said that before the world came into being, or before the Virgin gave birth, the possibility of these events must have existed previously, in a sense reference is made implicitly to the 'uncreated power'. ${ }^{6}$ But since the 'natures' of things were created by divine omnipotence, they too are dependent on it. That is why everything possible and impossible is determined by divine power. But divine power is either absolute power or ordained power. Thus, the possible and the impossible vary depending on whether they are related to absolute or ordained power. ${ }^{7}$ Yet the divine power is the divine will. For the will is generally a power which is directed towards an aim. ${ }^{8}$ Thus, the power represents the possibility, which the will actively implements. ${ }^{9}$

But what is it, the absolute and the ordered power? The $S H$ is characterized by the fact that it approaches this problem very carefully. It clearly distances itself from overly bold theories of omnipotence, according to which God can do anything we could imagine, even in disregard of the law of contradiction. One must - it reads there - while avoiding excessively brisk assertions, answer with all humility and bring to mind that it is the human soul which makes this division of the potentia $a b$ soluta and potentia ordinata. If the power of God is understood in the absolute sense, then the human soul 'could neither determine nor comprehend the infinite sea of His power.' But if the soul regards the divine power as an ordered power in the sense of power, truth and goodness, then everything is possible to God that does not derogate from its power, truth and goodness: i.e. he could not make himself de potentia ordinata greater than he is, because that would confuse the order of power; he could not disregard the law of contradiction, because that would disavow the order of thought; and he could not commit sin, condemn Peter and save Judas, because that would turn the moral order on its head. ${ }^{10}$

bilitas ad potentiam Dei, quae eadem semper fuit et erit: praedestinatio enim et potentia in Deo idem sunt.'

6 Alexander of Hales, Magistri Alexandri de Hales Glossa in quatuor libros Sententiarum Petri Lombardi, 4 vols (Quaracchi: Collegium S. Bonaventurae, 1951-57), vol. 1, d. 43, p. 441: 'Si vero possibile dicat dispositionem complexi, secundum hoc potest esse verum: “antequam pareret, Virginem parere est possibile;" cointelligitur enim ibi potentia increata, sicut si diceretur: antequam mundus foret, possibile est mundum fore. Ad illud vero quod obicitur: "quod aliquando fuit verum, prius fuit possibile," dicendum quod verum est secundum quod "possible" dicit dispositionem dicti et connotat potentiam increatam; secundum autem quod notat dispositionem rei subiectae, falsum est.'

7 SH IV, P3, In2, Tr1, M7, C4 (n. 688), p. 1093: 'Nota ergo quod necessarium opponitur impossibili et diversificatur secundum quod diversificatur impossibile. Impossibile autem et possibile respicit potentiam; potentia autem dicitur vel potentia prima simpliciter vel potentia ordinata.'

8 Alexander of Hales, Glossa, vol. 1, d. 1 (n. 16), p. 15: 'Nam ex parte eius qui fruitur, accipitur ipsa anima cuius est potentia, et ipsa potentia, et iterum ipsa ut inclinatur in finem et dicitur voluntas.' 9 Alexander of Hales, Glossa, vol. 1, d. 42 (n. 14), p. 432: 'Sed quia exsecutio potentiae in actum est a voluntate.'

10 SH I, P1, In1, Tr4, Q3, C3 (n. 155), p. 236: ‘[Solutio]: Ad hoc, nihil temere asserendo, cum omni modestia respondendum quod, si potentia Dei concipiatur ab anima absolute, non poterit anima determinare nec capere infinitum pelagus suae potestatis. Sed cum anima speculatur divinam potentiam ut ordinatam secundum conditionem potestatis, veritatis, bonitatis, dico quod possibile Deo est quod 
On the other hand, it says that God could de potentia absoluta condemn Peter and save Judas. ${ }^{11}$ How can that go together? How can something be possible de potentia absoluta and thus morally permitted, that de potentia ordinata is morally prohibited? The thesis, which is advocated in this paper and will be explicated in the following is: in the $\mathrm{SH}$ we have no dogmatic doctrine of the potentia absoluta and the potentia ordinata before us. Rather, it is used to be able to explain the possibility of our willing, i.e. the willing of created, rational beings. What is the condition of possibility of our willing? This is the key question of the $S H$ in this context. The answer of the $S H$ is: for our normal, 'orderly' willing we assume the potentia ordinata, for our 'disorderly' willing the potentia absoluta.

In this latter sense the distinction between the potentia absoluta and the potentia ordinata is also established. The absolute power refers to that which is not predetermined by a divine order; the ordained power, in contrast, refers precisely to this order predetermined by God. ${ }^{12}$ At times the potentia absoluta is also contraposed with the moral power (condecentia divinae bonitatis). The moral in a broad sense includes justice and equality as well as the disposition, i.e. the preordained and compassion. ${ }^{13}$ In relation to this potentia ordinata as a moral power, the potentia absoluta also appears as a potentia naturae. It is called so because it is from this that the will of what is impossible in nature becomes conceivable. Thus, the angel could only want to be everywhere de potentia naturae, yet not de potentia ordinata, because wanting to be everywhere at the same time would mean wanting to be God, and that is de potentia ordinata impossible. It is similarly the case with the possibility of not wanting to die. This possibility is not given for the potentia ordinata. This shows that the potentia absoluta is the willing of the impossible. ${ }^{14}$ Whoever recogniz-

posse potentiae est et non potest quod est impotentiae. Secundum hoc dixerunt, sicut habetur in libro De regulis Theologiae, quod quia contradicit suae potentiae vel veritati vel bonitati, potentiae maiestatis non conveniret ut faceret maiorem se; item, veritati eius contradiceret facere de eodem simul esse et non-esse; item, bonitati eius contradiceret damnare Petrum et salvare Iudam et peccare. Semper ergo cum debet dici aliquid Deo possibile, exigitur quod non detrahat potentiae eius, veritati vel bonitati.'

11 SH I, P1, In1, Tr4, Q2 (n. 141), p. 221: 'De potentia ergo absoluta posset damnare Petrum et salvare Iudam; de potentia vero ordinata secundum praeordinationem et retributionem secundum merita, non posset.'

12 SH I, P1, In1, Tr4, Q1, M2, C2 (n. 135), p. 207: 'Distinguitur ergo potentia absoluta [a] potentia ordinata. Potentia absoluta est eorum quorum non est divina praeordinatio; potentia vero ordinata est eorum quorum est divina praeordinatio, hoc est eorum quae a Deo sunt praeordinata sive disposita.' 13 SH I, P1, In1, Tr6, Q3, Ti2, M2, C3, Ar3 (n. 282), p. 393: 'Unde distinguendum est, quia in Deo est condecentia potestatis et est in eo condecentia sapientiae et condecentia dispositionis et condecentia aequitatis et condecentia miserationis: haec enim omnia complectitur condecentia divinae bonitatis.' 14 SH I, P1, In1, Tr2, Q3, Ti2, C5 (n. 44), p. 70: 'Ad ultimum dicendum quod duplex est potentia: scilicet potentia absoluta, quae dicitur potentia naturae, et potentia ordinata. Sic angelus de potentia naturae posset velle esse in omni "ubi”, sed non de potentia ordinata per gratiam: quia cum nihil posset esse ubique simul nisi Deus, si ipse vellet esse ubique simul, vellet esse Deus; quod non potest velle de potentia ordinata, licet possit de potentia naturae, quia, ut dictum est, ipsa est impossibili- 
es a miracle assumes an absolute power superior to nature. For what is impossible in the order of nature - such as that a tree trunk should become a cow - is in a Godrevocable order that is above the order of nature, i.e. through the potentia absoluta, quite possible. ${ }^{15}$

While the eternal punishment of a wrongdoer in hell appears to be possible from the potentia absoluta point of view, it is not possible from the standpoint of moral power, because it does not correspond to the overflowing moral goodness of God to punish without mercy. ${ }^{16}$ The incarnation of God - i.e. the incarnation as an event in this world - appears to us to be solely possible de potentia absoluta, while it is impossible according to the order of the potentia decens. As potentia absoluta, however, God is only nature or disposition, or only will, i.e. natural will, but not moral will. ${ }^{17}$ What the $S H$ wants to say is: we cannot integrate the incarnation of God as an event into the order of this world. We can merely explain it as the will of an absolute power. It looks different from the standpoint of faith, which regards everything as necessary in the sense of the non-contingent, that is, as morally necessary. From this point of view the distinction of the two kinds of divine power no longer matters. The incarnation of Christ is a necessity for the believer, even if the 'cause' - i.e. the circumstances, time and place, etc. - maintains its contingent character. It is necessary in the sense of the potentia ordinata, i.e. the moral power of God, which is the normal exercise of God's power. ${ }^{18}$

um. Loquendo de potentia absoluta, possem ego velle non mori, quia talis voluntas est impossibilium, sed non loquendo de potentia ordinata. Sic angelus de potentia naturae posset velle esse in omni "ubi", sed non de potentia ordinata per gratiam: quia cum nihil posset esse ubique simul nisi Deus, si ipse vellet esse ubique simul, vellet esse Deus; quod non potest velle de potentia ordinata, licet possit de potentia naturae, quia, ut dictum est, ipsa est impossibilium.'

15 SH I, P1, In1, Tr4, Q3, C4 (n. 156), p. 238: 'Et causa huius est, quia impossibile per se est de illis impossibilibus quae sunt impossibilia ex ordine naturae, ut truncum fieri vitulum, sunt [autem] possibilia ex ordine revocabili a Deo, qui est supra ordinem naturae.'

16 SH I, P1, In1, Tr6, Q3, Ti2, Ar3 (n. 282), p. 396: 'Ad illud quod quaeritur de punitione aeterna, "an scilicet Deus aliquem possit punire in inferno quantum meruit," dicendum quod dupliciter contingit loqui de potentia Dei: aut de potentia absoluta aut de potentia secundum condecentiam bonitatis. Loquendo ergo de potentia absoluta, dicendum quod posset; sed non de potentia quae est secundum condecentiam bonitatis, quia non decet suam bonitatem, quae est superabundans, quod ipse puniat absque misericordia.'

17 Alexander of Hales, Glossa, vol.1, d. 44 (n. 6), p. 448: 'Licet ergo posset incarnari quoad potentiam absolutam, non tamen quoad potentiam decentem.' Also SH I, P1, In1, Tr4, Q3, C2, Ar1 (n. 152), p. 234: 'Alia vero sunt quae non sunt in potentia activa nec passiva, ut ad hoc quod Deus fiat homo, et in iis solus Deus est natura sive dispositio divina sive voluntas.'

18 SH IV, P3, In2, Tr1, M7, C4 (n. 688), p. 1093: 'Impossibile autem et possibile respicit potentiam; potentia autem dicitur vel potentia prima simpliciter vel potentia ordinata. Quocumque autem modo accipiatur potentia, necessarium est Christum esse incarnandum, secundum quod accipitur pro hoc "ordinatum est quod Christus incarnabitur." Sed si accipiatur pro hoc "Christus incarnabitur," distinguendum est, scilicet quod duplicem habet comparationem: unam ad res, et secundum hoc habet contingentiam; alteram ad potentiam ordinatam, et secundum hoc habet necessitatem.' 
The possible in the sense of potentia ordinata thus encompasses everything that is feasible under the conditions of the majesty law (that is, the law of divine omnipotence ${ }^{19}$ ), the law of contradiction and the law of morality. What is striking is that the law of contradiction represents a limit of the potentia ordinata, not the potentia $a b$ soluta, and this together with other laws. A little later, already with Thomas Aquinas, the law of contradiction was declared the sole limit of the potentia absoluta, and in our context that means above all: omitting the moral law.

For the idea and expression of the 'potentia maiestatis' Alexander refers to the philosophy of the 12th century specially Bernard of Clairvaux but also to Alan of Lille. ${ }^{20}$ According to this idea is it the 'power of majesty'. So, God can do everything that does not represent an inability or a non-allowance (non decere). Impossible for God is therefore that which lacks the determinateness of the true and the good. ${ }^{21}$ Against this background, the potentia absoluta appears as a distant condition in order to explain the possibility of uncertain knowledge on the human side. But it finds its limit in the reality of the divine moral will: 'Even if he can do it de potentia absoluta, he only does what befits him. ${ }^{, 22}$ Yet it does not befit God to do or prescribe something outside of the order (inordinate). But then he cannot prescribe evil, because it could only be prescribed out of order: 'So he cannot "fornicate, kill, commit theft" because they are mala de se (bad in themselves), and so he cannot prescribe anything against the laws of the Decalogue, which are: You shall not fornicate; you shall not commit theft, etc. ${ }^{23}$ Hence there can be no other order for the divine will

19 See SH III, In3, Tr8, S1, Q1, p. 715: ‘Omnipotentia divinae maiestatis'; SH III, In3, Tr8, S1, Q3, Ti1, p. 779: 'Omnipotentia divinae maiestatis'. See n. 23 below.

20 Alexander of Hales, Glossa, vol. 1, d. 34, (n. 5), p. 350. See also SH I, P1, In1, Tr4, Q3, C3 (n. 155), p. 236: 'Secundum hoc dixerunt, sicut habetur in libro De regulis Theologiae, quod quia contradicit suae potentiae vel veritati vel bonitati, potentiae maiestatis non conveniret ut faceret maiorem se.' 21 Alexander of Hales, Glossa, vol. 1, d. 44 (n. 6), p. 448: 'Ad quod dicimus: Ad notitiam eorum quae hic dicuntur, notandum quod omnia potest Deus quae posse non est "non posse" vel "non decere." Licet ergo posset incarnari quoad potentiam absolutam, non tamen quoad potentiam decentem. Item, quaeritur, si Deus omnia possit, utrum simul possit opposita facere, ut simul in eodem scientiam et ignorantiam. Dicendum quod impossibile dicitur Deo, quod caret ratione veri boni que, et hoc est impossibile secundum genus; tale autem est prima contradictio et omnis oppositio in quantum habet primam oppositionem. Tale autem est hoc impossibile: facere maiorem se.' See also Alexander of Hales, Glossa, vol. 1, d. 42 (n. 11), p. 432: 'Colligitur ergo quod “omnia potest quaecumque posse potentia est; nam quaedam sunt quae magis est omnino non posse quam posse, magis infirmitatis indicia quam maiestatis insignia."

22 SH II, P1, In2, Tr3, S2, Q1, Ti2, M2, C5, Ar3 (n. 135), p. 183: 'Licet possit de potentia absoluta, non facit nisi quod decet ipsum.'

23 SH I, P1, In1, Tr6, Q3, Ti2, M2, C1, Ar3 (n. 276), p. 381: 'Ergo si non decet Deum aliquid inordinate agere, non faciet hoc ex libertate; sed similiter non decet ipsum praecipere inordinate; ergo si non potest facere nisi quod liberum est et decens, constat quod non potest malum praecipere, cum non possit praecipi nisi inordinate; ergo ista "fornicari, occidere, furtum facere," cum sint mala de se, non potest ista praecipere; et sic non potest praecipere contra praecepta Decalogi, quae sunt: Non fornicaberis, non furtum facies etc.' 
besides the moral. This unity and identity of the divine will is expressed in the $S H$ in a sentence that will later, in Duns Scotus, be reversed into its opposite: 'In God the ability de facto and the ability de jure are identical, insofar as the law means that which befits the divine benevolence. ${ }^{24}$

\section{Duns Scotus: Arbitrary Power and Ordained Power}

The doctrine of divine power in the $S H$ was very influential and determined the thought of the Franciscan tradition to a great extent. I do not need to trace in detail the different ways of reception of this teaching in Bonaventure and in his school, in Henry of Ghent, William of Ockham, throughout the 14th and 15th centuries, in Spanish scholasticism, in the 16th century with Puritan theologians in the Netherlands or England, in the 17th century not only with philosophers such as Descartes or Francis Bacon, but also with the jurists and especially in natural philosophy, i.e. in early modern science (with Gassendi, Sir Isaac Newton and Robert Boyle): the works of William J. Courtenay and F. Oakley have already accomplished this feat in a perfect form. ${ }^{25}$

Duns Scotus also belongs to this great Franciscan tradition. Yet he, indeed, changes everything. The basic thought of the $S H$, that in the case of the two kinds of power - potentia absoluta and potentia ordinata - we are dealing with two

24 SH I, P1, In1, Tr4, Q2, M2, C2 (n. 141), p. 220: 'In Deo idem est posse de facto et posse de iure, secundum quod ius dicit condecentiam bonitatis divinae.'

25 See William J. Courtenay, 'Potentia absoluta/ordinata,' in Historisches Wörterbuch der Philosophie, Bd. 7 (Basel: Schwabe, 1989), pp. 1157-62; idem, Capacity and Volition: A History of the Distinction of Absolute and Ordained Power (Bergame: P. Lubrina, 1990); F. Oakley, Omnipotence, Covenant, and Order: An Excursion in the History of Ideas from Abelard to Leibniz (Ithaca; London: Cornell University Press, 1984); idem, 'The Absolute and Ordained Power of God in Sixteenth- and Seventeenth-Century Theology,' Journal of the History of Ideas 59 (1998), pp. 437-61; idem, 'Voluntarist Theology and Earlymodern Science: The Matter of the Divine Power, Absolute and Ordained,' History of Science 56 (2018), pp. 72-96. One of the great changes in the minds of the interpreters mentioned by Oakley ('Voluntarist Theology and Early-modern Science,' p. 76) is his own shift to theological interpretation. While in his early works of the 1960s (especially about Pierre d'Ailly) none of this was perceptible - although H.A. Oberman's The Harvest of Medieval Theology (Cambridge, MA: Harvard University Press, 1963) had already been published - he later took over the theological interpretation as presented in the 1980s by Courtenay, Hamm, Greschat et al. of the relationship between potentia absoluta and potentia ordinata, which is called the 'covenental/dialectical theory.' This interpretation is theological because, from other contexts, it uses the idea of the covenant or the idea of promise or the later concept of God's self-commitment as a theological measure to make the relationship between the two types of power appear orthodox. The term 'dialectic' is also rather misleading, since neither the relationship of the potentia ordinata to the potentia absoluta nor the inverse relationship is to be thought of as a necessary change of the one into the other, but only subject to the unsearchable divine will. 
forms of the possible, he explicitly adopts. ${ }^{26}$ Yet what the $S H$ develops, as it were, as a transcendental groundwork becomes a dogmatic doctrine in Duns Scotus. This becomes clear in distinction 44 of the first book of Sentences, indeed in the Ordinatio as well as in the Lectura and the Reportatio Parisiensis. ${ }^{27}$ What Duns Scotus develops in this distinction is nothing less than the theory of arbitrary will, which is not bound by any law other than the law of contradiction. Yet, compared to the $S H$, this is already a fundamental change: while in the $S H$ the potentia ordinata has its limit in the already enacted laws (i.e. in the law of majesty [potential]), in the law of logic (i.e. the law of contradiction and in moral law), according to Duns Scotus the divine potentia absoluta (i.e. the field of the real possibilities) is now only limited by the law of contradiction.

The Scotist distinction 44 of the first book of Sentences begins with a philosophical-theological sensation: 'Not only in God, but in every free agent' (i.e. particularly in human will) the potentia absoluta and the potentia ordinata are to be distinguished - and thereby that which the jurists distinguish as de facto and de jure. ${ }^{28}$ Here Scotus' univocal concept of will is clearly recognizable in the background. In several passages he explicitly adverts to the same structure of the divine and human will. Thus the human will is also characterized by that indeterminateness by virtue of which it can determine itself by itself whether to pursue opposite, even contradictory possibilities. ${ }^{29}$ Furthermore, the human will, just as the divine, can be regarded as the reason for contingency. ${ }^{30}$ Duns Scotus goes even further in this parallelization. He says that 'now in each and every future moment as in the very first' God could establish a new order, just as we can act differently at any moment than we do. ${ }^{31}$ The distinction 44 proceeds from this univocal concept of will. The explanation of the conceptual pair potentia absoluta/ordinata following it has remained valid for centuries: the absolute power of God is the possibility given to the divine will, outside of the law given by God and, as the case may be (namely in that of human will) also to act 'against' it. This action is nonetheless 'ordinate', of course not according to the old order, but according to another moral order which the divine will establishes. ${ }^{32}$ The moral order is therefore something which has been established by the absolute divine will. One could call this moral positivism. In the case of the deviation from a given law the divine action nevertheless remains lawful, namely ac-

26 John Duns Scotus, Reportatio IV, d. 1, q. 5 (n. 2), in Opera Omnia, ed. L. Vivès (Paris: L. Vivès, 1891), 13:559a: 'Aliquid autem est possibile Deo dupliciter: vel secundum potentiam absolutam, (...) aut secundum potentiam eius ordinatam.'

27 John Duns Scotus, Ordinatio I, d. 44, q. 1 (Vatican City: Typis polyglottis Vaticanis, 1950 - 2017).

28 John Duns Scotus, Ordinatio I, d. 44, q. 1 (Vat. 14:363f.).

29 John Duns Scotus, Ordinatio I, d. 8, pt. 2, q. 1 (n. 298) (Vat. 4:324).

30 John Duns Scotus, Reportatio I, d. 40, q. 1 (n. 8) (Vivès, 22:475).

31 John Duns Scotus, Reportatio III, d. 18, q. 3 (n. 6) (Vivès, 23:393).

32 John Duns Scotus, Ordinatio I, d. 44, q. 1 (Vat. 6:366): 'Non quidem fieret ordinate secundum istum ordinem, sed fieret ordinate secundum alium ordinem, quem ordinem ita posset voluntas divina statuere sicut potest agere.' 
cording to another law, for God can 'change the law' and respectively establish another. And it is precisely this determination through the will alone, which constitutes the 'rightfulness' of the law. ${ }^{33}$ Hereby Duns Scotus thinks of the absolute divine power as well as the power of the absolute ruler. ${ }^{34}$

With regard to the definition of the terms potentia absoluta and potentia ordina$t a$, we have the following basic constellation, which has been established by Duns Scotus and which increases in sharpness and clarity in the course of nominalism, so that finally in Pierre d'Ailly, at the peak of this development, the last limit of divine omnipotence, namely the principle of contradiction, no longer applies: the 'ordained power' means the possible action within the frame of the laws given by God Himself. The divergence from these laws is possible for the divine as well as the human will through the absolute power. In the case of the human divergence from law, we are dealing with the phenomenon of 'guilt'. The divine divergence from its own laws, which does not occur according to any particular rule or law known to us, is instead understood as the sovereign establishment of a new order. Both kinds of divergence are an expression of arbitrariness. It is a form of 'freedom without reason' or 'abstract freedom without necessity,' which reigns here, and exactly these G.W.F. Hegel later names 'arbitrariness' (Willkür) as opposed to true freedom, which coincides with a particular form of necessity. ${ }^{35}$ Arbitrariness of that kind owes itself to the unholy alliance of power-ideology and voluntarism.

It is hardly disputed that in the work of Duns Scotus we are dealing with a form of voluntarism. Yet it is controversial whether it is a voluntarism mitigated by a kind of rationalism or an 'unmitigated voluntarism'. Thomas Williams has chosen one of the most voluntaristic-sounding Sentences in Scotus as the point of departure for his verification of the 'unmitigated voluntarism': 'Everything different to God is good, be-

33 John Duns Scotus, Lectura I, d. 44 (Vatican City: Typis polyglottis Vaticanis, 1950 - 2017), 17:535: 'Sed si illa (scilicet lex) subsit voluntati suae, bene potest de potentia absoluta quod non potest de potentia ordinata secundum illam legem; si tamen sic operetur, erit ordinata secundum aliam legem, - sicut, ponatur quod aliquis esset ita liber (sicut rex) quod possit facere legem et eam mutare, tunc praeter illam legem de potentia sua absoluta aliter potest agere, quia potest legem mutare et aliam statuere.' Idem, Ordinatio I, d. 44, q. 1 (n. 3) (Vat. 6:364): 'In omni agente libere - qui potest agere secundum dictamen legis rectae et praeter talem legem vel contra eam - est distinguere inter potentiam ordinatam et absolutam.' Idem, Ordinatio I, d. 44, q. 1 (Vat. 6:366): 'Ideo sicut potest aliter agere, ita potest aliam legen rectam stauere, - quae si statueretur a Deo, recta esset, quia nulla lex est recta nisi quatenus a voluntate divina acceptante est statute.'

34 John Duns Scotus, Ordinatio I, d. 44, q. 1 (nn. 3-7) (Vat. 6:364 sqq.); idem, Lectura I, d. 44, q. 1 (Vat. 17:535 sq.); idem, Lectura II, d. 7, q. 1 (nn. 26-28) (Vat. 19:8 sq.).

35 See also Thomas Williams, 'The Unmitigated Scotus,' Archiv für Geschichte der Philosophie 80:2 (1998), p. 10: 'Obviously, though, the principle once again seems to imply a certain arbitrariness on God's part.' For the opposition of arbitrariness and true freedom, see Hegel, Grundlinien der Philosophie des Rechts, in Werke in 20 Bänden, eds. Eva Moldenhauer and Karl Markus Michel, vol. 7 (Frankfurt am Main: Suhrkamp, 1970), pp. 65-66; Hegel, Vorlesungen über die Geschichte der Philosophie, in Werke in 20 Bänden, eds. Eva Moldenhauer and Karl Markus Michel, vol. 18 (Frankfurt am Main: Suhrkamp, 1971), p. 45. 
cause it is willed by God and not the other way around.' He has convincingly shown the voluntaristic background of transcendental and moral goodness. Great efforts have been made recently to exonerate Duns Scotus from the charge of 'unmitigated voluntarism'. ${ }^{36}$ Allen Wolter, Mary Beth Ingham, Richard Cross, and in Germany particularly Ludger Honnefelder and his colleagues have tried to 'mitigate' the Scotist voluntarism, which is not contested by anyone. ${ }^{37}$ In most cases, this is done by referring to the recta ratio, which plays a major role in the process of willing. Yet final doubts remain: there are indications that right reason (rechte Vernunft) does not have the last word, but instead is subordinated to the divine will, ${ }^{38}$ so that here we have before us an indication of that sentence by William of Ockham, which from an authoritative source had been designated as the origin of the so-called 'ethics of divine command': 'Solely because the divine will wants this, the right reason orders that one should want it.' Consequently, in this connection the recta ratio is regarded as the 'second-order moral principle. 39

36 The accusation that has always been raised has been renewed in an essay by Thomas Williams (see Williams, 'The Unmitigated Scotus') and in other works.

37 Allen B. Wolter, 'The Unshredded Scotus: A Response to Thomas Williams,' American Catholic Philosophical Quarterly 77:3 (2003), pp. 315-56; Mary Beth Ingham, 'Letting Scotus Speak for Himself,' Medieval Philosophy and Theology 10:2 (2001), pp. 173-216; Richard Cross, Duns Scotus (New York; Oxford: Oxford University Press, 1999), p. 190, n. 50; Ludger Honnefelder, Woher kommen wir? Ursprünge der Moderne im Denken des Mitteralters (Berlin University Press: Berlin, 2008), pp. 188-206; Isabelle Mandrella, Das Isaak-Opfer: Historisch-systematische Untersuchung zu Rationalität und Wandelbarkeit des Naturrechts in der mittelalterlichen Lehre vom natürlichen Gesetz, Beiträge zur Geschichte der Philosophie und Theologie des Mittelalters. Neue Folge, Bd. 62 (Münster: Aschendorff, 2002), pp. 132-50. On the other hand, Mandrella, Das Isaak-Opfer, as well as in other works has gained the merit, to have drawn attention to the anticipation of the etsi Deus non daretur principle - which is usually only associated with the name Hugo Grotius - in Gregory of Rimini and thus in a kind of Platonism at the height of the period of voluntarism. See for example Isabelle Mandrella, 'Die Autarkie des mittelalterlichen Naturrechts als Vernunftrecht: Gregor von Rimini und das etiamsi Deus non daretur-Argument,' in Herbst des Mittelalters? Fragen zur Bewertung des 14. und 15. Jahrhunderts, eds. Jan Aertsen and Martin Pickavé (Berlin: Walter de Gruyter, 2004), pp. 265-76. Another mitigating tendency towards voluntarism also can be found in H. Möhle, Ethik als Scientia practica nach Johannes Duns Scotus: Eine philosophische Grundlegung, Beiträge zur Geschichte der Philosophie und Theologie des Mittelalters. Neue Folge, Bd. 44 (Münster: Aschendorff, 1995), which for the first time opened up to us the world of Scotist practical philosophy. Strikingly - since they both want to 'mitigate' voluntarism - Möhle, Ethik, p. 361, agrees with Wolter, 'daß das Naturgesetz nur insofern verpflichtenden Charakter hat, als es von Gott gewollt wird' ['that the law of nature is only binding in so far as it is willed by God.']

38 See also John Duns Scotus, Reportatio 1 A, d. 44, q. 2, in Johannes Duns Scotus: Pariser Verlesungen über Wissen und Kontingenz, ed. and trans. Joachim R. Söder (Freiburg im Breisgau: Herder, 2005), 206: 'Nihil est melius simpliciter recta ratione quin inquantum volitum a Deo. (...) Unde auctoritas nihil vult dicere nisi quod quodcumque Deus fecit, hoc scias eum recta ratione fecisse; omnia enim quaecumque voluit fecit.'

39 William of Ockham, Ordinatio I, d. 41, q. 1, in Guillelmi de Ockham. Scriptum in librum primum Sententiarum: ordinatio, distinctiones XIX-XLVIII, eds. Girard I. Etzkorn and Francis E. Kelly (St Bonaventure, NY: St Bonaventure University, 1979), p. 610. For the later reception of the sentence in vol- 
What can furthermore be seen as an indication of an 'unmitigated voluntarism' is the fact that in connection with the question of the validity of natural law, in Duns Scotus precisely the intellectual constellation surfaces, which will later determine the discussion at the height of the voluntaristic development with a historical reminiscence of the so-called dilemma of Euthyphro. Already in Scotus the voluntaristic position is contraposed with the opinion according to which the good is a good in and of itself: 'The good is good indeed not because it is prescribed, or bad because it is forbidden (like the instruction not to eat the apple), but rather conversely, because it is good it is prescribed. ${ }^{40}$ It is argued against this position in the name of voluntarism: 'if all instructions of the Decalogue innately had such an intrinsic goodness, then God could not dispense with them because they would not be subject to the divine will (...) yet, if furthermore the opposite act were innately bad in itself, then it would thus follow that the law would not be within the divine power, but instead exist above it (...). ${ }^{41}$ Hence we already have here in Duns Scotus this classical constellation which will characterize the later voluntarism as such: on one side the Platonic being-in-itself (An-sich-Sein) of good and evil, on the other side the dependence of the prescriptions of the Decalogue of the divine will.

In the background of this issue lies the question raised by Plato if the good is good because the gods will it, or if they will the good because it is good and valuable in itself. Platonism of all times has always taken the latter position: what good and evil are, cannot be traced back to a will (not even that of the gods) as their reason. The theological voluntarism of the 14th and 15th centuries has performed a complete turn-around on this question. It is immediately noticeable in that the initial Platonic question - if the good is good because the gods will it or if the gods will it because it is good - is now in the times of voluntarism answered in opposition to the spirit of Platonism. ${ }^{42}$ A sentence directed against Plato, which is circulated throughout the entire Nominalist movement, reads in Pierre d'Ailly, so to speak on the pinnacle of voluntarism thus: 'God prescribes the good not because it is good nor forbids the bad because it is bad, but instead it is good, because it is bidden and bad because it is forbidden. ${ }^{43}$ It reads similarly in Gabriel Biel from the perspective of moral positivism: 'Not because something is righteous or just is it willed by God, but because

untarism see especially J.M. Idziak, Introduction to Andrew of Neufchateau, O.F.M., Questions on an Ethics of Divine Commands, ed. and trans. J.M. Idziak (Notre Dame: University of Notre Dame Press, 1997), pp. xi-xliii, on p. xx.

40 John Duns Scotus, Lectura III, d. 37 (Vat. 21:350): 'Non enim ideo sunt bona quia praecipiuntur, vel mala quia prohibentur (sicut praeceptum "de non comedendo pomum”), sed magis e converso "quia bona, ideo praecepta.",

41 John Duns Scotus, Lectura III, d. 37 (Vat. 21:352).

42 See further Theo Kobusch, Die Philosophie des Hoch- und Spätmittelalters, Geschichte der Philosophie, Bd. 5 (Munich: C.H. Beck, 2011), pp. 481-82, 491.

43 Pierre d'Ailly, In Sent. I, q. 14, ar. 1b, in Questiones super libros sententiarum (Frankfurt am Main: Minerva, 1968): 'Nec ideo precipit (Deus) bona quia bona sint, vel prohibet mala quia mala sint, sed (...) ideo bona sunt quia precipiuntur, et mala quia prohibentur.' 
God wills it, it is just and righteous. ${ }^{, 44}$ The formulation, which as such goes back to an older tradition, in the times of voluntarism presents the alternative in its contrary exclusiveness, while a compatibility was otherwise conceivable. ${ }^{45}$ There is not good or evil in itself which God necessarily loves or hates, but instead all positive moral qualities are what they are because of the love (i. e. the 'acceptance') of God. And correspondingly all negative moral qualities are not despicable because of their nature i.e. in themselves detestable to God - not even the hate of God itself, but instead they are credited to man as eternal punishment 'solely on the basis of the pure divine will. ${ }^{, 46}$

As we have seen already in Duns Scotus, the notions of arbitrariness, of moral positivism and the unpredictability of the divine will connected with them, lie at the center of voluntarism. The criticism of this voluntaristic conception which already begins in the Middle Ages confirms this in an effective manner. As I have expounded upon this in detail elsewhere, I can here limit myself to references. ${ }^{47}$ The famous etsi Deus non daretur argument, which stems from Gregory of Rimini, is the first form of the criticism of voluntarism. It lies at the core of a Platonic position: even if there is no divine will, the validity of the moral laws is not questioned. ${ }^{48}$

The severest and most sustained criticism of theological voluntarism comes from large parts of modern philosophy. The Cambridge Platonists, above all R. Cudworth, yet also H. More, G. Rust and others, the English deists (A. Collins, M. Tindal, Th. Morgan), Leibniz, C. Wolff and his school, and not least the whole tradition of classical German philosophy (Kant, Fichte, Hegel, Schelling) submit the voluntaristic doctrine to an unambiguous criticism: the moral good is not good, because God wills it; it is desired by any will, because it is good in itself. Closely connected with this is the tenet of the univocity of the moral, which is clearly formulated by the Cambridge Platonists and adopted by the others. It too is directed against voluntarism.

44 Gabriel Biel, Collectorium I, d. 17, q. 1, dub. 4, 44-45, in Collectorium circa quattuor libros Sententiarum, ed. W. Werbeck (Tübingen: Mohr Siebeck, 1973), p. 423; Gabriel Biel, Collectorium II, d. 37, ar. 3, dub. 1, (Werbeck, p. 643).

45 For the history of the formulation, see Jacob Schmutz, 'Was Duns Scotus a Voluntarist? Juan Caramuel Lobkowitz against the Bratislava Franciscans,' Filosofický časopis (2016), pp. 147-84, esp. p. 152.

46 Pierre d'Ailly, In Sent. II, principium D (cf. In Sent., principium E and In Sent. II, princ. Q): 'Nullum est ex se peccatum sed precise quia lege prohibitum.' In Sent. I 9 R: 'Nullum est bonum vel malum quod Deus de necessitate sive ex natura rei diligat vel odiat. (...) Nec aliqua qualitas est ex natura rei iusticia sed ex mera (...) Acceptatione divina.' In Sent. I 9 P: 'Nec odium Dei nec alius quicumque actus culpabilis est Deo odibilis ex natura rei sive ex sui natura. Patet: nullus talis actus deacceptatur ad vitam aeternam vel imputatur ad penam aeternam nisi ex mera voluntate divina.'

47 Theo Kobusch, 'Das Moralische: Der absolute Standpunkt: Kants Metaphysik der Sitten und ihre Herausforderung für das moderne Denken,' in Freiheit nach Kant: Tradition, Rezeption, Transformation, Aktualität, eds. S. Josivovic and J. Noller (Leiden; Boston: Brill, 2019), pp. 54-92; idem, Selbstwerdung und Personalität, pp. 323-33; idem, 'Wer Großes will, muß sich beschränken können': Vom Wesen des Moralischen (Basel: Schwabe, 2018), pp. 27-31.

48 Cf. Kobusch, Die Philosophie des Hoch- und Spätmittelalters, pp. 423-25, 490 - 93. 
Finally, another idea directed against voluntarism was born in the 17th and 18th centuries, within the so-called 'second' or 'Spanish scholasticism', from where it was adopted in the other philosophical systems. This is the idea of the modalities proper to the realm of the moral. The possibility within this realm is what Kant calls the 'permitted' (Erlaubtes), while the 'moral necessity', which also determines the willing of God (Leibniz: necessitas moralis ad optimum), is the highest form of freedom. This tenet too is frontally directed against the theological voluntarism. $^{49}$

To summarize: The etsi Deus non daretur argument, the principle of univocity of the moral and the principle of moral necessity confirm ex negativo that the god of voluntarism is a god of arbitrariness, i.e. a god who deals with reasons which are known only to him and are beyond our research, who always acts orderly, but can change the 'orders', including the moral order, whose will is the reason for all contingency, without him being bound to a kind of necessity (as e.g. the moral necessity), with the exception of the law of contradiction. The god of voluntarism is, like the absolute ruler, unpredictable. The origins of such absolute power can be found in the thought of Duns Scotus, more specifically in his doctrine of the potentia absoluta, not in the $\mathrm{SH}$ nor in the early Franciscans - quod erat demonstrandum.

49 Regarding the idea of moral necessity see Sven K. Knebel, Wille, Würfel und Wahrscheinlichkeit: Das System der moralischen Notwendigkeit in der Jesuitenscholastik 1550-1700 (Hamburg: Meiner, 2000); idem, 'Necessitas Moralis ad Optimum (I): Zum historischen Hintergund der Wahl der besten aller möglichen Welten,' Studia Leibnitiana 23 (1991), pp. 3-24; idem, 'Necessitas Moralis ad Optimum (II): Die früheste scholastische Absage an den Optimismus: Eine unveröffentlichte Handschrift Jorge Hemelmans S.J. von 1617,' Theologie und Philosophie 67 (1992), pp. 514-35; idem, 'Necessitas Moralis ad Optimum (III): Naturgesetz und Induktionsproblem in der Jesuitenscholastik während, des zweiten Drittels des 17. Jahrhunderts,' Studia Leibnitiana 24:2 (1992), pp. 182-215. 
